\title{
Pattern, Challenges and Prospect of Livelihood Diversification Through Small Business. A Comparative Study in Three Climatic Zone of Rural Ethiopia
}

\author{
Mesfin Seyoum \\ School of Policy Studies, Ethiopian Civil Service University, PO Box 5648, Addis Ababa, Ethiopia
}

\begin{abstract}
The study is aimed at exploring patterns and prospects of livelihood diversification through small business using a comparative study in three climatic zone of rural Ethiopia. Although rural households, who are primarily agricultural, used to deploy their resources between farm and rural small business to diversify incomes and reduce the inherent risk embedded in the dependence of agricultural production, little attention is given by policy makers to diversification out of agriculture as a peasant survival strategy. With respect to the types of small business, participant households in all climatic zone are engaged in different business activities from which goat, sheep, fatten ox and chat trading are the major one. To exploit the benefit that could be obtained from small business and thereby improve food security in the rural area, proper attention should be given by the government to enhance the existing small business as expansions of such schemes are a necessary condition for the gradual reduction of agricultural labor force.
\end{abstract}

Keywords: Livelihood diversification, Small business, Rural households

DOI: $10.7176 / \mathrm{EJBM} / 11-28-01$

Publication date:October $31^{\text {st }} 2019$

\section{Introduction}

In most Sub-Saharan African (SSA) countries, rural households are frequently not able to support themselves from their farms income (Deborach 1999). In these regard, many researchers also confirmed that, in rural area of Ethiopia the number of poor people exceeds the capacity of agriculture to provide sustainable livelihood opportunities. Ellis (1999) noted that farming on its own is increasingly unable to provide a sufficient means of survival in rural areas.

Although rural households, who are primarily agricultural, used to deploy their resources between farm and non-farm activities to diversify incomes and reduce the inherent risk embedded in the dependence of agricultural production, little attention is given by policy makers to diversification out of agriculture as a peasant survival strategy (Block \&Webb 2001). In fact, small business development in rural area has fallen in to an "Institutional Vacuum", since it has not belonged to the domain of Agricultural Ministries, with their mandate related to farming per se, or to that of Industry Ministries, which commonly focus on urban large-scale, companies (Tassew 2000). The conventional sector based approach employed to analyze the Ethiopian economy, categorizing it as agriculture- industry have contributed to the relative neglect of the rural small business development.

In these regard, present Ethiopian government is criticized by some quarters for pursuing rural development policies that neglect the role of small business in rural areas. It has been and still is unclear which government organization is responsible for the promotion of small business in rural areas. Its contribution in decreasing rural urban migration, employment creation, reduce rural poverty, increase income and improve household welfare absorbing the growing rural labor force and promoting a more equitable distribution of income are downplayed(Davis \& Pearce 2000).

Therefore, the study is aimed at exploring patterns and prospects of livelihood diversification through small business using a comparative study in three climatic zone of rural Ethiopia. In this regard, the empirical evidences will be taped concerning the extent and nature of small business in addition to analyzing the proportion of households participating in the business in the three agro-ecological zone.

\section{Literature Review}

\subsection{Determinants to the Growth of Small Business}

- Human Capital

Human capital comprises the skills, knowledge, and ability to labor and good health important to the ability to pursue different livelihood strategies. The existence of an excessive labor supply can also be a stronger stimulus to the diversification in to RNF activities (Ellis 2000).

\section{- Social Capital}

Social capital comprises the social resources (e.g. networks, membership of groups, relationships of trust, access to wider institutions of society) upon which people drawn in pursuit of livelihoods. There is ample evidence of influence of social capital on access to different types of employment (Davis 2004). 


\section{- Physical Capital}

Physical capital includes hard infrastructure (e.g. roads telecommunications, power and water), as well as production equipment and buildings that are more likely to be individually owned. There is a consensus in the literature on the critical role of infrastructure in the development of the RNF economy (Deverseux \& Maxwell (eds), 2001).

\section{- Financial Capital}

One of the principal problems for rural households and individuals wishing to start a business are access to capital or credit. Without start-up funds or with only little cash available for investment, households are limited to a small number of activities that yield poor returns. While there is wide and growing experience with micro-credit in Ethiopia, the vast majority of rural people do not have access to any such scheme. Many authors comment on the consequent importance of informal source of credit (Rearden 1997).

\section{- Natural Capital}

Natural Capital comprises the natural resources such as water, land and common property resources that are so central to rural livelihoods. These resources provide a foundation for much of the small business (Ellis 1999).

\section{Research Methodology}

\subsection{Data Types and Data Sources}

The research attempted to use qualitative and quantitative method. Both primary and secondary data sources have been employed. Through such a mixed way of data generation the limitation of one was offseted by the other.

\subsection{Sampling Procedures and Sample Size}

Both probability and non-probability sampling techniques was used to collect data at different stages. To select the study districts, out of a total of 40 districts found in the study area, 3 districts was selected based on purposive sampling technique. This enabled to compare and contrast the situation of small enterprises in Wet Land(Oda Jalela), Semi-Arid(Lege Lencha) and Arid(Mede Telila) Districts.

To reach to the intended target sample, using districts roster, total population was stratified in to three wealth groups, rich, medium and poor. With regard to sample size, the following sample size determination table is used where it is determined to be 150 households.

Table 3.1: Sample size determination table

\begin{tabular}{|l|l|l|l|l|}
\hline No & Population Size & \multicolumn{3}{l|}{ Sample size } \\
\cline { 3 - 5 } & & Low & Medium & High \\
\hline 1 & $51-90$ & 5 & 13 & 20 \\
\hline 2 & $91-150$ & 8 & 20 & 32 \\
\hline 3 & $151-280$ & 13 & 32 & 50 \\
\hline 4 & $281-500$ & 20 & 50 & 80 \\
\hline 5 & $501-1200$ & 32 & 80 & 125 \\
\hline 6 & $12001-3200$ & 50 & 125 & 200 \\
\hline 7 & $3201-10000$ & 80 & 200 & 315 \\
\hline 8 & $100001-35000$ & 125 & 315 & 500 \\
\hline 9 & $35001-150000$ & 200 & 500 & 800 \\
\hline
\end{tabular}

Source: (Malhetra, 2007)

Table 3.2: Income Strata and Proportionally Selected Sample Households

\begin{tabular}{|l|l|l|l|}
\hline No & $\begin{array}{l}\text { Households by wealth } \\
\text { status }\end{array}$ & $\begin{array}{l}\text { Size of Households by } \\
\text { wealth }\end{array}$ & $\begin{array}{l}\text { Proportional and randomly Selected sample } \\
\text { size }\end{array}$ \\
\hline 1 & Rich & 1482 & 20 \\
\hline 2 & Medium & 2116 & 28 \\
\hline $\mathbf{3}$ & Poor & 7707 & 102 \\
\hline & Total Population & 11305 & 150 \\
\hline
\end{tabular}

Source: (Field Data, 2018)

\subsection{Method of Data Collection}

Primary data was collected through household survey using structured questionnaires, in-depth interview and the focus group discussions was used. Moreover, Published and unpublished documents including progress reports, previous research documents, and compiled data were reviewed to get background information about rural small businesses. 


\section{Findings and Discussions}

From all 150 sample size, 60households are participants in different business activities while 90 of them were not participated in any business activities. Non participants were also studded to uncover the entry barriers to the business.

\subsection{Types of business}

Table 4.1: Participant households in Three Districts

\begin{tabular}{|l|l|l|l|l|l|}
\hline \multirow{2}{*}{ No } & \multirow{2}{*}{ Types of small business } & \multicolumn{4}{l|}{ Participant households by Districts } \\
\cline { 3 - 6 } & & Wet land & Semi-Arid & Arid & Total \\
\hline 1 & Local drink sale & $2(7.4)$ & $1(5.3)$ & - & $3(5)$ \\
\hline 2 & Small shop & $3(11.1)$ & $2(10)$ & $2(14.3)$ & $7(11.6)$ \\
\hline 3 & Fruit and vegetables trading & $1(3.7)$ & $1(5.3)$ & - & $2(3.3)$ \\
\hline 4 & Grain trading & $4(14.8)$ & - & $2(14.3)$ & $6(10)$ \\
\hline 5 & Carpentry & $1(3.7)$ & $1(5.3)$ & $1(7.1)$ & $3(5)$ \\
\hline 6 & Chat trading & $6(22.2)$ & $4(21.1)$ & $3(21.4)$ & $13(21.7)$ \\
\hline 7 & Coffee trading & $3(11.1)$ & $2(10.5)$ & - & $5(8.3)$ \\
\hline 8 & Fatten ox Trading & $3(11.1)$ & $3(15.8)$ & $2(14.3)$ & $8(13)$ \\
\hline 9 & Goat \& sheep Trading & $4(14.8)$ & $5(26.3)$ & $4(28.6)$ & $13(21.7)$ \\
\hline Total & & $27(45)$ & $19(31.7)$ & $14(23.3)$ & $60(100)$ \\
\hline
\end{tabular}

* The Number in the bracket indicates Percentages out of hundred

Source: (Field Data, 2018)

Of all types of RNF activities in the study area, chat, goat and sheep trading were dominant that accounts to $13(21.7 \%)$ households. These are followed by 8 (13.3\%) fatten ox trading and 7 (11.6\%) small shop trading. Moreover, the distributions in the types of business taken up in the three climate zone showed marked variation. These reveal that the potentials of the three climatic zone to pursue small business are different.

\subsection{Major Sources of Initial Capital}

A household's prior wealth is an important determinant of the degree and nature of small enterprises growth.

Table 4.2: Sources of Initial Capital by Districts Administration

\begin{tabular}{|l|l|l|l|l|l|}
\hline \multirow{2}{*}{$\begin{array}{l}\text { Study } \\
\text { Sites }\end{array}$} & \multicolumn{4}{|l|}{ Sources of initial capital } & \multicolumn{3}{l|}{\begin{tabular}{l} 
Micro finance \\
\cline { 2 - 6 } Institutions
\end{tabular}} & Total \\
\hline Wet Land & $15(55.6)$ & $7(25.9)$ & $5(18.6)$ & - & $27(100)$ \\
\hline Semi-Arid & $11(57.9)$ & $4(21)$ & $4(21)$ & - & $19(100)$ \\
\hline Arid & $8(57.1)$ & $3(21.4)$ & $3(21.4)$ & - & $14(100)$ \\
\hline Total & $34(56.7)$ & $14(23.3)$ & $12(20)$ & & $60(100)$ \\
\hline
\end{tabular}

* The Number in the bracket indicates Percentages out of hundred Source: Own survey, 2018

With respect to the sources of start-up capital, as shown in the above table, the results of the study clearly indicate that out of the total business operators surveyed, $34(56.7 \%)$ of them use Iqub and their own savings while $14(23.3 \%)$ of them received money as a gift from relatives as their initial sources of capital. Only $12(20 \%)$ business operators have used credit from NGOs as their initial sources of capital for their business. Generally, Iqub, own savings, and gifts from relatives are found to be the main sources that are followed by NGOs. The assumption was credits from government-financed institution play a very important role in financing business at initial stage but the result of this survey shows that credit from government is not a major source of initial capital.

\subsection{Major Sources of Skill to Run Small Business}

Literature gives evidence that training is positively associated with small enterprises development. The following Table 12 depicts the result of the study on the sources of skills that enabled the business operators to be engaged in the types of business that they are undertaking. 
Table 4.3: Major Sources of Skill and Training

\begin{tabular}{|l|l|l|l|l|l|l|}
\hline \multirow{2}{*}{$\begin{array}{l}\text { Climate } \\
\text { zone }\end{array}$} & \multicolumn{2}{|l|}{ Source of Skill used by the participant households } \\
\cline { 2 - 7 } & $\begin{array}{l}\text { From parents } \\
\text { family } \\
\text { tradition) }\end{array}$ & $\begin{array}{l}\text { From } \\
\text { friends }\end{array}$ & $\begin{array}{l}\text { From government } \\
\text { financed training } \\
\text { programs }\end{array}$ & $\begin{array}{l}\text { Own effort } \\
\text { Funded } \\
\text { Training } \\
\text { programs }\end{array}$ & Total \\
\hline Wet Land & $5(18.5)$ & $3(11.1)$ & - & $14(51.9)$ & $5(18.5)$ & $27(100)$ \\
\hline Semi-Arid & $2(10.5)$ & $4(21.5)$ & - & $10(52.6)$ & $3(15)$ & $19(100)$ \\
\hline Arid & $1(7.1)$ & $3(21.4)$ & - & $8(57.1)$ & $2(14.3)$ & $14(100)$ \\
\hline Total & $8(13.3)$ & $10(16.7$ & - & $32(53.3)$ & $10(16.7)$ & $60(100)$ \\
\hline
\end{tabular}

* The Number in the bracket indicates Percentages out of hundred

Source: own survey, 2018

Of the total business operators surveyed, $8(13.3 \%)$ households have learnt the skill from parents (family) and $32(53.3 \%)$ households have reported that they learnt by own effort. In this regards, the study show that there is no one that was benefited from government formal training centers. Rather those that are benefited from NGOs funded training programs accounts to $10(16.7 \%)$ households.

The focus group participants also confirmed that operators of local drink sale, small shops and other businesses in all study areas are mostly inherited the technical skill from their parents and family members. With regard to the question towards the availability of government business development system (BDS) to start nonfarm business, majority of the focus group paricipants reported that there was no advisory services to motivate them start and run their business.

4.4 Sources of Market Information to Business Operators

Table 4.4 Major Source of Market Information

\begin{tabular}{|c|c|c|c|c|c|}
\hline \multirow[t]{2}{*}{ Climate Zone } & \multicolumn{4}{|c|}{ Source of Market Information } & \multirow[b]{2}{*}{ Total } \\
\hline & $\begin{array}{l}\text { Friends } \\
\text { \& Relatives }\end{array}$ & $\begin{array}{l}\text { Associations } \\
\& \text { NGOs }\end{array}$ & No Source & $\begin{array}{l}\text { Government } \\
\text { Institution }\end{array}$ & \\
\hline Wet Land & $15(55.6)$ & $7(25.9)$ & $2(7.4)$ & $3(11.1)$ & $27(100)$ \\
\hline Semi-Arid & $14(73.7)$ & $3(15.8)$ & - & $2(10.5)$ & $19(100)$ \\
\hline Arid & $9(64.3)$ & $3(21.4)$ & - & $2(14.3)$ & $14(100)$ \\
\hline Total & $38(63.3)$ & $13(21.7)$ & $2(3.3)$ & $7(11.7)$ & $60(100)$ \\
\hline
\end{tabular}

* The Number in the bracket indicates Percentages out of hundred

Source: Own survey, 2009

As depicted in the above table, the results of the study have shown that from the total business operators, 38 $(63.3 \%)$ households have responded that friends and relatives are served as the main sources of information that are followed by $13(21.7 \%)$ respondents who have benefited from NGOs. However, $2(3.3 \%)$ of the business operators replied that they undertook their business without any market information due to either low level of awareness about the importance of marketing information, or lack of access to marketing information or both.

\subsection{Business Entry Barriers}

Table 4.5: Major Entry Barriers to Non-participant Households

\begin{tabular}{|l|l|l|l|l|l|}
\hline \multirow{2}{*}{\begin{tabular}{l} 
Zlimate \\
\cline { 2 - 5 }
\end{tabular}} & \multicolumn{4}{|l}{ Entry Barriers to Non-participant Households (N=90) } \\
initial capital & $\begin{array}{l}\text { Lack of } \\
\text { Market }\end{array}$ & $\begin{array}{l}\text { Lack of } \\
\text { technical } \\
\text { skill }\end{array}$ & $\begin{array}{l}\text { Lack of Business } \\
\text { development } \\
\text { Service }\end{array}$ & Total \\
\hline Wet Land & $7(30.4)$ & $2(8.7)$ & $4(17.4)$ & $10(43.5)$ & $23(100)$ \\
\hline Semi-Arid & $9(29.3)$ & $12(38.7)$ & $6(19.4)$ & $4(12.9)$ & $31(100)$ \\
\hline Arid & $3(8.3)$ & $15(41.7)$ & $12(33.3)$ & $6(16.7)$ & $36(100)$ \\
\hline Total & $19(21)$ & $29(32.1)$ & $22(24.4)$ & $20(22.2)$ & $90(100)$ \\
\hline
\end{tabular}

* The Number in the bracket indicates Percentages out of hundred Source: (Field Study, 2018)

In wet land (Oda Jalela district), the major entry barriers encountered by the non-participant households are lack of inputs $10(43.5 \%)$ and lack of initial capital 7(30.4\%). These followed by lack of technical skill 4(17.4\%) and lack of inputs 2(8.7\%). With regards to Semi-Arid (Lege Lencha district), lack of business awareness $12(38.7 \%)$ and lack of initial capital $9(29.3 \%)$ are their major challenges. they also suffer from problems like lack of technical skill 6(19.4\%) and lack of inputs 4(12.9\%). Concerning Arid (Mede Telila district), lack of business 
awareness $15(41.7 \%)$ and Lack of technical skill 12(33.3\%) are their major challenges.

Generally, no differences have been observed among the three-interviewee groups in specifying initial capital as the requirements to start small business. The implication is that access to finance; business awareness, market and other infrastructure are among the major factors, which determine the success of the small business in the rural area. Moreover, almost all focus group discussants reported that availability of all-weather roads and access to transport facilities play a major role in minimizing transaction costs and in saving working time.

From the above discussions, it is clear that, even though peasants do have extra time, which enables them to be involved in rural small business activities and there are push factors i.e inability to satisfy their food requirement from agricultural production, their involvement in income generating activities through small business is limited/minimal.

\subsection{Households' Business Prospect}

Those individuals with little or no experience of small business may not trust their ability to participate successfully and may decide to settle in agricultural activities in which they feel more confident.

Table 4.6: Households' Business Prospect

\begin{tabular}{|c|c|c|c|c|c|c|}
\hline \multirow[t]{3}{*}{ Climate Zone } & \multicolumn{6}{|c|}{ Household heads livelihood vision in the coming five years } \\
\hline & \multicolumn{3}{|c|}{ Participant Households $(\mathrm{N}=60)$} & \multicolumn{3}{|c|}{ Non- Participant Households $(\mathrm{N}=90)$} \\
\hline & $\begin{array}{l}\text { Remain } \\
\text { in farm } \\
\text { only }\end{array}$ & $\begin{array}{l}\text { Do both } \\
\text { farming and } \\
\text { non-farming } \\
\text { business }\end{array}$ & $\begin{array}{l}\text { Do only } \\
\text { non-farm } \\
\text { business }\end{array}$ & $\begin{array}{l}\text { Remain in } \\
\text { farm only }\end{array}$ & $\begin{array}{l}\text { Do both } \\
\text { farming and } \\
\text { non- } \\
\text { farming } \\
\text { business }\end{array}$ & $\begin{array}{l}\text { Do only } \\
\text { non-farm } \\
\text { business }\end{array}$ \\
\hline Wet Land & $1(3.7)$ & $19(70)$ & $7(25.9)$ & $15(65.2)$ & $8(34.8)$ & - \\
\hline Semi-Arid & $2(10.5)$ & $13(57.9)$ & $4(26.3)$ & $20(64.5)$ & $10(32.3)$ & $1(3.2)$ \\
\hline Arid & $3(21.4)$ & $8(57.1)$ & $3(21.4)$ & $14(38.9)$ & $22(61.1)$ & - \\
\hline Total & $6(10)$ & $40(63.3)$ & $14(23.3)$ & $49(54.4)$ & $40(44.4)$ & $1(1.1)$ \\
\hline
\end{tabular}

*The $\%$ age is taken from all participants $(\mathrm{N}=60)$ or non-participants $(\mathrm{N}=90)$

Source: (Field Data 2018)

The respondents were also asked what they would like to do most in the next five years. As shown in the above table, $6(10 \%)$ households responded that they would prefer to do farming only while $40(66.7 \%)$ of them replied that they would like to do both farming and non-farming activities. The rest, that is, $15(25 \%)$ participant households responded that they would prefer to do non-farm business only. With regard to non-participants, 49 $(54.4 \%)$ of them want to remain in farm only while $40(44.4 \%)$ of them want to do both farming and non-farming business. Only $1(1.1 \%)$ of them want to do non-farm business which shows that they have little awareness about RNF activities.

With regard to participant households vision, 3(21.4\%) participant households in arid climate, and 2(10.5\%) participant households in semi-arid climate want to remain in farm activities. Only 1(3.7\%) participant households in wet land reported that they want to remain in farm activities. These reveal that as rural communities' are getting remote with unfavorable climate, the degree of households' awareness and participation to small business activities decreases.

Generally, while 49 (54.4\%) of the non-participant households reported that they want to remain in the farm activities, only $6(10 \%)$ of the business participant responded that they want to remain in the farm activities. Again, when $40(63.3 \%)$ of the business participant reported that they want to do both farming and non-farming activities, only $40(44.4 \%)$ of the non-participant households reported in the same manner. These show that non-participant households have less awareness about the benefits and contributions of rural small business to livelihood security compared to participant households which implies that there is a need for government and other development agents' interventions to promote the awareness of the non-participants.

\section{CONCLUSIONS}

With respect to the types of small business, participant households in all climatic zone are engaged in different activities from which goat, sheep, fatten ox and chat trading are the major one.

Small business diversification is more pronounced in wet land than in semi-arid and arid districts. The implication is that, where there is population density and hence land fragmentation, households tend to pursue multiple small business as copping strategies.

Regarding the sources of start-up capital, the result of the study indicates that equib and own savings and gifts from relative are found to be the main sources of startup capital. The assumption was credit from governmentfinanced institution played a very important role in financing business at initial stage but the result of this analysis shows that credit from government is not a major source of initial capital.

To exploit the benefit that could be obtained from small business and thereby improve food security in the 
rural area, proper attention should be given by the government to enhance the existing small business as expansions of such schemes are a necessary condition for the gradual reduction of agricultural labor force.

\section{Bibliography}

Block, S. and Webb, P., 2001. "Dynamics of Income Diversification in Ethiopia: Evidence from Pane Data,". Elsevier, Vol. 26(4), Pages 333-350. Elsevier B.U.

Bryceson, Deborach., 1999. 'Sub-Saharan African Betwixt and Between: Rural Livelihood practices and policy.' ASC De-Agrarianisation and Rural Employment Net work Working Paper. 43/1999.

Davis J. and Pearce, D., (2000). "The Rural Non-Farm Economy in Central and Eastern Europe”, Discussion Paper No 2000/04, Chatham: NRI.

Davis, J.R. (2004). The Rural Non-Farm Economy, Livelihoods and Their Diversification: Issues and Options. Chatham, UK Natural Resources Institute.

Deverseux. S. and Maxwell S. (eds), 2001. Food Security in Sub-Saharan Africa. ITDG Publishing: UK.

Ellis, F. (2000). "Rural Livelihoods and Diversity in Developing Countries," Journal of oxford University Press, New York.

Reardon, T. (1997). "Using Evidence of Household Income Diversification to Inform Study of the Rural NonFarm Labor Market in Africa".

Tassew Woldehanna, 2000. Economic Analysis and Policy Implication of Farm and off-farm Employment, A Case study in the Tigray Region of Northern Ethiopia, Wageninges. 